\title{
Pengembangan Modul Pembelajaran Berbasis Realistic Mathematic Education Untuk Meningkatkan Kemampuan Berpikir Kreatif Matematis Siswa Pada Materi Bangun Ruang Sisi Datar
}

\author{
Ade Siti Rahma ${ }^{1}$, Edi Syahputra ${ }^{2}$, Mulyono $^{3}$ \\ 1,2,3Prodi Pendidikan Matematika Pascasarjana, Universitas Negeri Medan \\ Universitas Negeri Medan, Jalan William Iskandar Pasar V, Medan, Indonesia \\ ade.sitirahma@gmail.com
}

\begin{abstract}
This study aims to 1) develop a learning module based on Realistic Mathematical Education on valid, practical, and effective flat-sided geometry material; 2) To improve students' mathematical creative thinking skills by using a learning module based on Realistic Mathematical Education on the material of flat side space. This research is development research modified from the Thiagarajans' Model by developing a learning module based on Realistic Mathematics Education (RME). This research will be carried out at MTs Islamiyah Belawan in the even semester of the 2020/2021 school year. The subjects in this study were students of class VIII MTs Islamiyah Belawan. The results showed that 1) The validation of the learning module based on Realistic Mathematical Education that was developed was in the 'Valid' category in terms of the analysis of the results of the validity of the learning module by the validator with a total average value of 3.78 . the criteria for the practical success of the learning module in terms of the results of the observation of the implementation of learning, and the learning module developed has met the established effectiveness criteria; 2) Based on the normalized gain index, it was found that in the first trial there was an increase in the value of 0.42 with moderate criteria $(0.3<\mathrm{g} \leq 0.7)$ and in the second trial there was an increase in the value of 0.44 with moderate criteria $(0.3<\mathrm{g} \leq 0.7)$.
\end{abstract}

Keywords: Realistic Mathematical Education, Mathematical Creative Thinking Ability, Learning Module Development

\begin{abstract}
Abstrak
Penelitian ini bertujuan untuk 1) Untuk mengembangkan modul pembelajaran berbasis Realistic Mathematic Education pada materi bangun ruang sisi datar yang valid, paktis, dan efektif; 2) Untuk meningkatkan kemampuan berpikir kreatif matematis siswa dengan menggunakan modul pembelajaran berbasis Realistic Mathematic Education pada materi bangun ruang sisi datar. Penelitian ini adalah penelitian pengembangan yang dimodifikasi dari Model Thiagarajan dengan mengembangkan modul pembelajaran berbasis Realistic Mathematics Education (RME). Penelitian ini akan dilaksanakan di MTs Islamiyah Belawan pada semester genap tahun pelajaran 2020/2021. Subjek dalam penelitian ini adalah siswa kelas VIII MTs Islamiyah Belawan. Hasil penelitian menunjukkan bahwa 1) Validasi modul pembelajaran berbasis Realistic Mathematic Education yang dikembangkan berada pada kategori 'Valid' ditinjau dari analisis hasil validitas modul pembelajaran oleh validator dengan nilai rata-rata total sebesar 3,78, Modul pembelajaran berbasis Realistic Mathematic Education yang dikembangkan memenuhi kriteria keberhasilan kepraktisan modul pembelajaran ditinjau dari hasil observasi keterlaksanaan pembelajaran, dan Modul pembelajaran yang dikembangkan telah memenuhi kriteria keefektifan yang ditetapkan; 2) Berdasarkan indeks gain ternormalisasi, diperoleh bahwa pada uji coba I terjadi peningkatan nilai sebesar 0,42 dengan kriteria sedang $(0,3<g \leq 0,7)$ dan pada uji coba II terjadi peningkatan nilai sebesar 0,44 dengan kriteria sedang $(0,3<g \leq 0,7)$.

Kata kunci: Realistic Mathematic Education, Kemampuan Berpikir Kreatif Matematis, Pengembangan Modul Pembelajaran
\end{abstract}

Copyright (c) 2022 Ade Siti Rahma, Edi Syahputra, Mulyono

$\triangle$ Corresponding author: Ade Siti Rahma

Email Address: ade.sitirahma@gmail.com (Jalan William Iskandar Pasar V, Medan, Indonesia)

Received 02 February 2022, Accepted 18 February 2022, Published 24 February 2022

\section{PENDAHULUAN}

Pembelajaran yang perlu diperhatikan adalah pembelajaran matematika, karena banyak hal dalam kehidupan kita yang berhubungan dengan matematika (Zaqiyah et al., 2020). Matematika merupakan mata pelajaran yang diberikan disetiap jenjang pendidikan dan mutlak harus ada di 
sekolah. Dalam belajar matematika diperlukan kesiapan intelektual dan kemampuan kognitif yang memadai. Siswa tidak hanya sekedar menghafal teori atau rumus saja, tetapi juga lebih menekankan pada terbentuknya proses pengetahuan sehingga belajar bukan sekedar transfer ilmu dari guru kepada siswa, melainkan juga suatu proses yang dikondisikan untuk dapat membangun sendiri kemampuan siswa dan terjadi interaksi serta memberikan manfaat bagi dirinya sendiri.

Namun dalam pembelajaran matematika saat ini banyak siswa yang kesulitan untuk mempelajari dan memahami materi matematika. Dalam proses pembelajaran untuk meningkatkan kemampuan berpikir kreatif matematis siswa dibutuhkan suatu bahan ajar yang didesain khusus. Untuk itu perlu menciptakan pembelajaran yang baik dan berhasil melalui tersedianya fasilitas belajar seperti bahan ajar yang menarik, sesuai dan relevan sehingga dapat meingkatkan pemahaman konsep dan minat belajar matematika siswa (Lasmiyati \& Idris, 2014).

Bahan ajar adalah semua hal yang dimanfaatkan oleh guru pada kegiatan belajar (Nasiroh, 2014). Bahan ajar adalah segala bentuk bahan yang digunakan untuk membantu guru dalam melaksanakan kegiatan belajar dan pembelajaran. (Noviarni, 2014). Bahan ajar hendaknya dirancang dan ditulis sesuai dengan kaidah pembelajaran, yakni disesuaikan materi pembelajaran, disusun berdasarkan atas kebutuhan pembelajaran, terdapat bahan evaluasi, dan menarik untuk dipelajari oleh siswa.

Berdasarkan hasil wawancara peneliti dengan salah satu guru bidang studi matematika di MTs Islamiyah Belawan. Diperoleh informasi bahwa pelaksanaan pembelajaran yang ada di sekolah MTs Islamiyah Belawan di kelas masih banyak yang didominasi guru saja (teacher center), sedangkan siswa hanya datang, duduk, dengar, catat, dan menghafal, keadaan seperti ini memberikan dampak buruk bagi siswa, salah satunya adalah siswa hanya menguasai materi yang diberikan tanpa mengetahui manfaat dan cara mengaplikasikan ilmu atau pelajaran tersebut dalam kehidupan seharihari. Selain itu, bahan ajar yang digunakan terkategori kurang layak untuk digunakan dalam proses pembelajaran. Sumber belajar berupa buku paket matematika siswa saja masih kurang mencukupi untuk digunakan siswa ketika belajar. Artinya ada sebagian siswa yang tidak memiliki buku pelajaran. Selain buku pelajaran, Lembar Aktivitas Siswa (LAS) yang digunakan juga masih kurang menarik dari segi tampilan (desain), tulisan dalam LAS kurang jelas dengan font tulisan yang terlalu kecil menjadikan siswa kesulitan untuk membaca dan memahami isi LAS tersebut. Selain kekurangan pada desain, LAS yang digunakan hanya berisi ringkasan materi, rumus-rumus, dan soal-soal yang jauh dari realistik sehingga siswa mengalami kesulitan dalam mengerjakan latihan soal yang diberikan. Soal yang diberikan masih bersifat abstrak, masih kurang mengaitkan dengan kehidupan sehari-hari dan materi-materi lainnya. Akibatnya kemampuan berpikir matematika siswa masih rendah. Jika sistem pembelajaran seperti ini masih sering berlangsung, ada beberapa kemungkinan buruk yang akan terjadi, antara lain siswa menjadi kurang tertarik pada pelajaran, kemudian timbulnya kejenuhan, rasa bosan, bersikap pasif terhadap pelajaran dan kemungkinan terburuknya adalah siswa sudah tidak mau 
belajar matematika atau benci dengan mata pelajaran matematika.

Pada temuan lain, berpikir kreatif yang dimiliki siswa SMP dalam menyelesaikan permasalahan matematika masih dalam kategori rendah. Hal ini diperkuat dari hasil penelitian Fardah (dalam Putra, dkk, 2018) menyatakan bahwa sebanyak siswa memiliki kemampuan berpikir kreatif pada kategori rendah. Temuan Meika \& Sujana (dalam Putra et al., (2018)) pada salah satu sekolah menengah diperoleh informasi bahwa rata-rata persentase kemampuan berpikir kreatif siswa sebesar , sehingga dapat dikatakan kemampuan berpikir kreatif siswa masih tergolong rendah. Berdasarkan hasil penelitian Fardah serta Meika \& Sujana dapat diasumsikan bahwa kemampuan berpikir siswa sekolah menengah di Indonesia itu masih sangat rendah. Selain itu, berdasarkan observasi peneliti di SMP Negeri 5 Purworejo yang mengacu pada indikator berpikir kreatif yaitu kelancaran, keluwesan, keaslian, dan keterincian, Isaksen, dkk (Istikomah et al., 2020) masih banyak siswa yang belum mampu mencapai indikator berpikir kreatif tersebut. Guru diharapkan dapat menciptakan pembelajaran yang bermakna, menyenangkan, serta melibatkan siswa secara aktif dalam menghasilkan gagasan atau jawaban sendiri sesuai kemampuannya (Putra et al., 2018). Kebermaknaan belajar sebagai hasil dari kegiatan mengajar ditandai oleh terjadinya hubungan antara aspek, konsep, informasi atau situasi baru dengan komponen yang relevan didalam struktur kognitif siswa. Pembelajaran matematika perlu dirancang sedemikian sehingga berpotensi mengembangkan kemampuan berpikir kreatif siswa (Moma, 2016).

Salah satu upaya yang dapat dilakukan adalah mengembangkan suatu bahan ajar berupa modul untuk mempermudah siswa dalam mempelajari materi dan sebagai sumber belajar atau rujukan yang akan disesuaikan dengan kebutuhan dan karakteristik siswa secara menyeluruh. Modul adalah alat pembelajaran yang disusun sesuai dengan kebutuhan belajar pada mata pelajaran tertentu untuk keperluan proses pembelajaran tertentu (Hamdani, 2011).

Modul yang diciptakan oleh pengajar dalam bentuk satu paket lengkap yang tersusun secara sistematis, yang didalamnya terdapat bukan hanya teori-teori pembelajaran tetapi terdapat lembar kegiatan dan latihan-latihan soal (Ataji \& Sujarwanta, 2020). Pemilihan modul ini penting sebagai bentuk usaha untuk meningkatkan kemandirian siswa dalam belajar, usaha tersebut dicetuskan untuk memudahkan guru mengontrol kegiatan siswa dan kemajuan belajar siswa, sedangkan untuk siswa sebagai bahan pemicu kreatifitas dan merangsang berpikir kritis.

Realistic Mathematics Education (RME) merupakan suatu pendekatan pembelajaran matematika yang melibatkan realitas dan pengalaman siswa. Pendekatan RME memberikan kesempatan kepada siswa untuk menemukan kembali dan menkonstruksi konsep-konsep matematika berdasarkan pada masalah realistik yang diberikan oleh guru, karena siswa membangun sendiri pengetahuannya, maka siswa tidak akan mudah lupa. Selain itu, suasana dalam proses pembelajaran menjadi lebih menyenangkan karena menggunakan realitas kehidupan (Chisara et al., 2018). Hal tersebut juga sejalan dengan Chotimah (Chotimah, 2015) bahwa pendekatan RME dapat menciptakan siswa lebih aktif, kreatif, berfikir, dan berani mengemukakan pendapat, serta dapat membuat suasana 
pelajaran matematika lebih kreatif dan menyenangkan. Pendekatan ini bukan semata-mata menyangkut kegiatan guru mengajar akan tetapi menitikberatkan pada aktivitas belajar siswa, dan membimbing siswa memperoleh suatu kesimpulan yang benar.

Dalam pembelajaran matematika diperlukan kemampuan pemahaman konsep yang tepat untuk menyelesaikan suatu masalah. Menurut Mayasari et al (Mayasari et al., 2018) dalam pembelajaran matematika bukan hanya penguasaan materi yang harus dimiliki siswa, namun perlu adanya kemajuan berpikir dalam diri siswa yang mampu menunjang dalam menyelesaikan suatu permasalahan yang sedang dihadapi. Adapun kemampuan berpikir yang tumbuh dalam diri siswa saat pembelajaran matematika adalah kemampuan berpikir kreatif, kritis, logis, analitis dan kompleks. Kemampuan berpikir ini yang nantinya dapat membantu siswa dalam menyelesaikan persoalanpersoalan matematika, baik dalam pembelajaran maupun dalam kehidupan seharihari.

Kemampuan berpikir yang akan diukur pada penelitian ini adalah kemampuan berpikir kreatif. Berpikir kreatif baik dalam hal umum maupun dalam matematika merupakan bagian dari keterampilan hidup yang sangat diperlukan siswa dalam menghadapi kemajuan IPTEKS serta tantangan, tuntutan, dan persaingan global yang semakin pesat (Hendriana et al., 2017). Selain itu proses berpikir secara kritis dan kreatif dengan HOTS dapat mendorong siswa untuk bisa melakukan penalaran tingkat tinggi sehingga tidak hanya terpaku pada satu pola jawaban yang dihasilkan dari proses menghafal tanpa mengetahui konsep ilmunya. Sebagian siswa belum bisa menganalisis soal, jika hal ini terus berlanjut, siswa akan mengalami kesulitan dalam menyelesaikan soal bertipe HOTS (Chuseri et al., 2021).

Namun kenyataan yang terjadi di lapangan pada tahap observasi tanggal 8 Maret 2021 dilakukan kepada siswa langsung untuk mengerjakan soal matematika yang dalam penelitian ini menggunakan materi bangun ruang sisi datar (prisma dan limas) terlihat banyak kekeliruan dalam jawaban siswa. Kesalahan jawaban siswa tersebut dikarenakan siswa kurang memahami konteks masalah pada soal. Hal tersebut harus membuat para guru juga harus tahu pendekatan, metode dan strategi yang tepat untuk meningkatkan kemampuan pemahaman konsep matematika siswa. Dalam proses pembelajaran, aktivitas siswa dimulai dengan observasi, kemudian mengajukan pertanyaan, mencoba, membuat jaringan, dan menganalisis (Surya \& Syahputra, 2017).

Pada penelitian sebelumnya Putri (Putri et al., 2019) yaitu "Learning devices based on realistic mathematic education approaches developed have met effective criteria and can improve mathematical spatial ability and students motivation. The mathematics learning devices developed can facilitate teachers and students at school." Mereka menyatakan bahwa perangkat pembelajaran berbasis RME yang dikembangkan dapat meningkatkan kemampuan spasial dan motivasi dalam belajar. Dari hasil penelitian sebelumnya ini terlihat RME memiliki keunggulan dalam hal meningkatkan kemampuan matematik seperti spasial pemahaman konsep dan dalam penelitian ini yang akan ditingkatkan adalah berpikir kreatif matematis. 
Untuk itu, peneliti akan melaksanakan penelitian dengan judul "Pengembangan Modul Pembelajaran Berbasis Realistic Mathematic Education untuk Meningkatkan Kemampuan Berpikir Kreatif Matematis Siswa Pada Materi Bangun Ruang Sisi Datar”.

\section{METODE}

Penelitian ini adalah penelitian pengembangan yang dimodifikasi dari Model Thiagarajan (Thiagarajan, Semmel, 1974) dengan mengembangkan modul pembelajaran berbasis Realistic Mathematics Education (RME) atau Pendekatan Matematika Realistik. Penelitian ini akan dilaksanakan di MTs Islamiyah Belawan pada semester genap tahun pelajaran 2020/2021. Subjek dalam penelitian ini adalah siswa kelas VIII MTs Islamiyah Belawan dan sebagai objek dalam penelitian ini adalah modul pembelajaran berbasis Realistic Mathematics Education (RME) atau Pendekatan Matematika Realistik.

Pengembangan modul dalam penelitian ini menggunakan model pengembangan Thiagarajan 4-D (define, design, develop, dan disseminate) yang telah dimodifikasi. Tahap penyebaran (disseminate) merupakan tahapan sosialisasi modul pembelajaran yang telah final, kegiatan penyebaran ini tetap dilakukan, hanya saja terbatas pada forum musyawarah guru mata pelajaran di sekolah tempat dilakukan penelitian. Selain modul pembelajaran juga dikembangkan Rancangan Pelaksanaan Pembelajaran (RPP) berbasis Realistic Mathematics Education, instrumen penelitian berupa tes kemampuan berpikir kreatif matematis, lembar respon siswa, dan lembar validasi. Modifikasi pengembangan modul pembelajaran model 4-D dalam penelitian ini disajikan seperti pada Gambar 1.

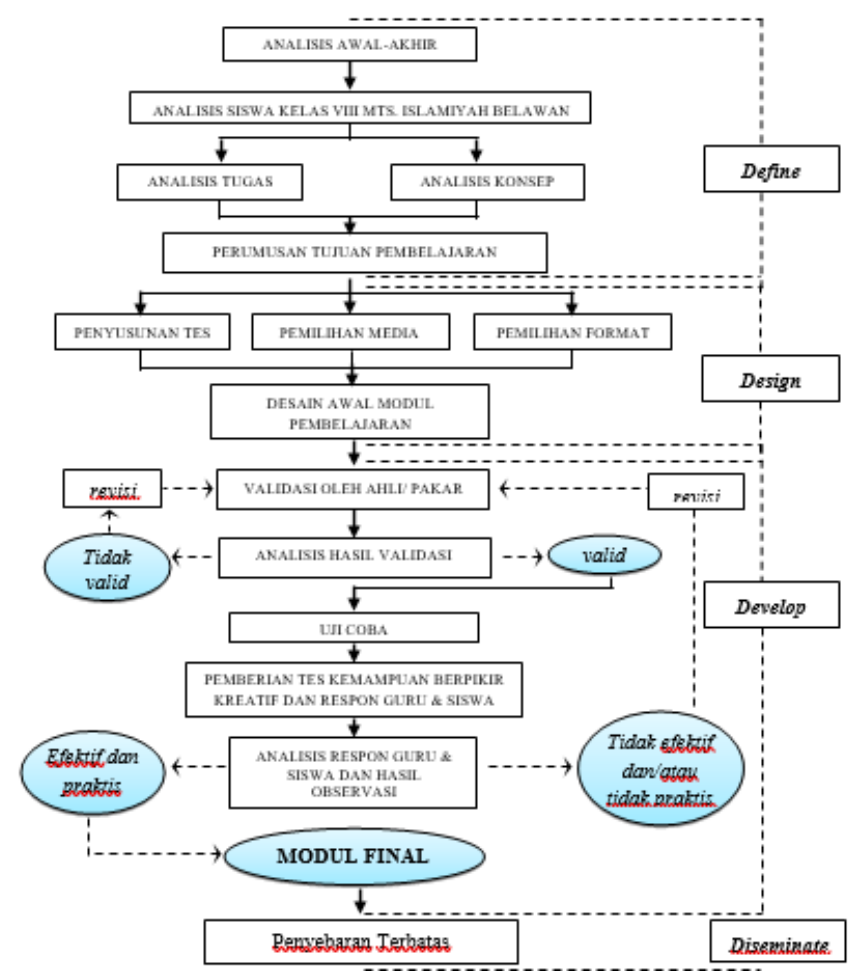

Gambar 1. Bagan Pengembangan Modul pembelajaran Model 4-D 


\section{Keterangan:}

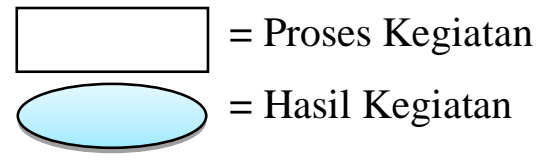

$$
\begin{aligned}
\longrightarrow & =\text { Alur utama } \\
---\rightarrow & =\text { Menunjukkan hasil }
\end{aligned}
$$

Instrumen penelitian dan teknik pengumpulan data disusun untuk mengukur kevalidan, kepraktisan dan efektivitas pengembangan modul pembelajaran dengan pendekatan RME. Untuk mengukur kevalidan instrumen yang digunakan dalam penelitian ini adalah lembar validitas modul pembelajaran terdiri dari lembar validasi RPP dan lembar validasi tes kemampuan berpikir kreatif matematis. Untuk mengukur kepraktisan instrumen yang digunakan dalam penelitian ini adalah angket respon siswa dan pedoman wawancara guru terhadap modul pembelajaran dan instrumen efektivitas modul pembelajaran dilihat dari hasil tes berpikir kreatif matematis siswa.

\section{HASIL DAN DISKUSI}

Produk dari penelitian ini berupa modul pembelajaran matematika pada materi pokok bangun ruang sisi datar (prisma dan limas) untuk siswa SMP/MTs kelas VIII yang pembuatannya berbasis Realistic Mathematic Education. Desain penelitian ini dilakukan melalui 4 tahap utama, yaitu define (pendefinisian), design (perancangan), develop (pengembangan), dan disseminate (penyebaran) sebagaimana dijabarkan sebagai berikut.

\section{Deskripsi Tahap Pendefinisian (Define)}

Berdasarkan hasil observasi awal terhadap ketersediaan perangkat pembelajaran di MTs Islmaiyah Belawan bahwa RPP yang digunakan masih dalam bentuk RPP yang belum sesuai dengan kurikulum pembelajaran. Lembar Aktivitas Siswa (LAS) belum pernah dimanfaatkan dalam pembelajaran sehingga menyebabkan siswa kurang terlatih dalam mengasah kemampuan matematikanya serta buku ajar yang digunakan sangat minim sekali bahkan tidak mencukupi kebutuhan siswa dan belum melengkapi standar materi yang dipelajari, tidak memuat peta konsep dan kurang menyajikan masalah pada setiap soal yang digunakan untuk mengukur kemampuan berpikir kreatif siswa.

Selain itu guru tidak melatih kemampuan berpikir kreatif siswa yang berperan meningkatkan keaktifan siswa dan membantu proses pemahaman siswa terhadap materi yang diajarkan, guru kurang memberi motivasi belajar terhadap siswa dan cenderung tidak ada. Hal inilah yang mendorong peneliti untuk mengembangkan modul beserta perangkat pembelajaran dengan menggunakan pendekatan berbasis Realistic Mathematic Education (RME) untuk meningkatkan kemampuan berpikir kreatif, yang diharapkan dapat menjadi perangkat pembelajaran matematika yang efektif dan praktis di sekolah. 


\section{Deskripsi Tahap Perancangan (Design)}

\section{Perancangan Modul}

Modul yang dikembangkan disusun agar siswa memiliki pedoman dalam memahami materi pelajaran sesuai dengan tujuan pembelajaran yang ditetapkan. Modul yang dikembangkan memuat masalah-masalah yang kontekstual yang harus diselesaikan secara kelompok dan mandiri. Selanjutnya dalam setiap sub bab disajikan masalah-masalah yang pemecahannya mengarah pada proses siswa menemukan setiap konsep-konsep luas permukaan dan volume bangun ruang sisi datar (prisma dan limas) dengan tahapan penyelesaian iceberg. Kemudian dalam setiap subbab diberikan contoh soal serta alternatif penyelesaian untuk menambah pemahaman siswa dalam memecahkan masalah serta diberikan soal-soal uji kompetensi berbasis kemampuan berpikir kreatif. Kemudian tampilan bentuk visual dari materi pembelajaran bangun ruang sisi datar seperti Gambar 2. berikut ini:

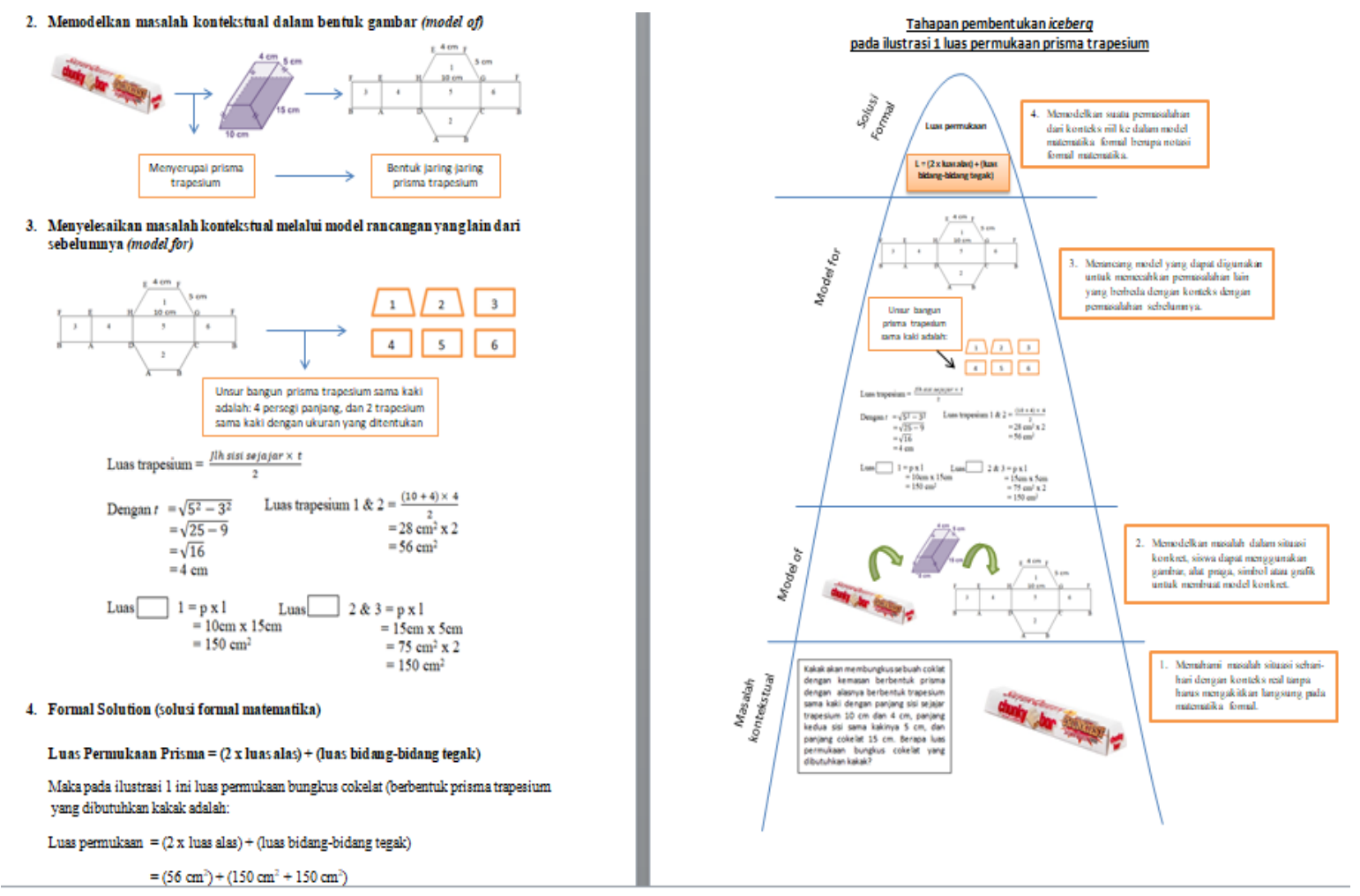

Gambar 2. Materi Bangun Ruang Sisi Datar

\section{Perancangan Rencana Pelaksanaan Pembelajaran (RPP)}

Rencana Pelaksanaan Pembelajaran (RPP) terdiri dari 4 kali pertemuan. RPP sesuai dengan prinsip dan karakteristik dari penyusunan RPP pada kurikulum 2013 yang terdiri dari: (1) satuan pendidikan; (2) mata pelajaran; (3) kelas/semester; (4) materi; (5) alokasi waktu; (6) kompetensi inti; (7) kompetensi dasar; (8) indikator pembelajaran; (9) tujuan pembelajaran; (10) materi pembelajaran; (11) pendekatan/model/metode; (12) media/sumber dan bahan pembelajaran; (13) kegiatan pembelajaran; (14) penilaian; (15) instrumen penilaian hasil belajar. Langkah-langkah pembelajaran mengacu pada pendekatan Realistic Mathematic Education (RME). 


\section{Perancangan Lembar Aktivitas Siswa (LAS)}

Lembar aktivitas siswa (LAS) terdiri dari 4 set untuk 4 kali pertemuan. LAS yang dikembangkan sesuai dengan prinsip atau prosedur pendekatan Realistic Mathematic Education (RME). Pada LAS disediakan tempat untuk menuliskan nama kelompok, anggota kelompok, serta jawaban untuk setiap pertanyaan. LAS berisi soal berpikir kreatif yang disesuaikan dengan persoalan pada modul pembelajaran, sehingga modul dan LAS dalam penelitian ini merupakan bagian yang tak terpisahkan.

\section{Perancangan Tes Kemampuan Bepikir Kreatif Matematis}

Penyusunan tes kemampuan berpikir kreatif matematis berdasarkan indikator dan berbentuk uraian yang terdiri dari 4 butir soal. Dalam menyusun tes kemampuan berpikir kreatif dilakukan kegiatan, yaitu: (1) membuat kisi-kisi tes; (2) merancang masalah sesuai indikator kemampuan berpikir kreatif matematis yang mengacu pada indikator yang ingin dicapai; (3) membuat alternatif penyelesaian/kunci jawaban tes; dan (4) membuat pedoman penskoran kemampuan berpikir kreatif matematis.

\section{Deskripsi Tahap Pengembangan (Develop)}

1. Validitas

Hasil Uji Validitas ahli

Adapun hasil validasi ahli terhadap modul pembelajaran dapat dilihat pada Tabel 1. Berikut:

Tabel 1. Hasil Validasi Ahli Terhadap Modul Pembelajaran Dengan Rata-Rata Total

\begin{tabular}{|l|c|c|c|}
\hline No & Bahan & Rata-rata Total & Kategori \\
\hline $\mathbf{1}$ & Modul Pembelajaran & 3,78 & Valid \\
\hline $\mathbf{2}$ & RPP & 3,78 & Valid \\
\hline $\mathbf{3}$ & LAS & 3,71 & Valid \\
\hline $\mathbf{4}$ & Tes Kemampuan Berpikir Kreatif & 3,76 & Valid \\
\hline
\end{tabular}

Berdasarkan Tabel 1. terlihat bahwa nilai rata-rata total validasi modul pembelajaran oleh para ahli dan materi adalah sebesar 3,78 dimana sesuai dengan kriteria kevalidan berada pada kategori "Valid". Dari Tabel juga terlihat bahwa nilai rata-rata total validasi untuk RPP sebesar 3,78 (kategori "Valid"). Selanjutnya, nilai ini dirujuk pada kriteria kevalidan yang telah ditetapkan, maka dapat disimpulkan bahwa RPP yang dikembangkan memenuhi kriteria kevalidan dengan kategori valid. Dan dari Tabel terlihat bahwa nilai rata-rata total validasi untuk LAS sebesar 3,71. Selanjutnya, nilai ini dirujuk pada kriteria kevalidan yang telah ditetapkan, maka dapat disimpulkan bahwa LAS yang dikembangkan memenuhi kriteria kevalidan dengan kategori valid. Begitu pula dengan penilaian valid kepada soal tes kemampuan berpikir kreatif matematis siswa

\section{Hasil Uji Validitas Butir Soal pre-tes dan post-test Kemampuan Berpikir Kreatif Matematis}

Uji coba tes kemampuan berpikir kreatif matematis bertujuan untuk mengetahui validitas dan reabilitas serta tingkat kesukaran dari soal test kemampuan berpikir kreatif matematis siswa. Hal ini akan mempengaruhi kesejajaran dengan skor total sehingga dapat digunakan sebagai alat evaluasi 
kemampuan berpikir kreatif matematis diakhir pembelajaran. Uji validitas, reabilitas dilakukan melalui uji coba terhadap siswa yang lain dengan karakteritik yang sama. Berdasarkan rumus korelasi product moment, diperoleh validitas setiap butir pre-tes dan post-test disajikan pada Tabel 2. dan Tabel 3. sebagai berikut:

Tabel 2. Validitas Butir Pretes Kemampuan Berpikir Kreatif Matematis

\begin{tabular}{|c|c|c|c|c|}
\hline No & $r_{x y}$ & $t_{\text {hitung }}$ & $t_{\text {tabel }}$ & Interpretasi \\
\hline 1 & 0.89 & 9.56 & 2.02 & Valid \\
\hline 2 & 0.92 & 11.5 & 2.02 & sangat Valid \\
\hline 3 & 0.87 & 8.64 & 2.02 & Valid \\
\hline 4 & 0,82 & 7.01 & 2.02 & Valid \\
\hline
\end{tabular}

Tabel 3. Validitas Butir Posttest Kemampuan Berpikir Kreatif Matematis

\begin{tabular}{|c|c|c|c|c|}
\hline No & $r_{x y}$ & $t_{\text {hitung }}$ & $t_{\text {tabel }}$ & Interpretasi \\
\hline 1 & 0,96 & 16.8 & 2.02 & sangat Valid \\
\hline 2 & 0.95 & 14.07 & 2.02 & sangat Valid \\
\hline 3 & 0,98 & 24.1 & 2.02 & sangat Valid \\
\hline 4 & 0,95 & 16.08 & 2.02 & sangat Valid \\
\hline
\end{tabular}

Berdasarkan data pada tabel di atas, interpretasi dari masing- masing butir pre-tes dan posttest berada pada kategori Sangat valid. Dengan demikian berdasarkan perhitungan yang dilakukan dengan manual menggunakan excel, maka disimpulkan bahwa semua butir pre-tes dan post-test tersebut dapat dikatakan layak digunakan.

\section{Praktikalitas}

Deskripsi hasil obesrvasi keterlaksanaan pembelajaran menggunakan modul pembelajaran yang dikembangkan pada uji coba II dapat dilihat pada Tabel 4.

Tabel 4. Deskripsi Hasil Observasi Keterlaksanaan Pembelajaran Pada Uji Coba II

\begin{tabular}{|l|l|c|c|c|c|}
\hline \multirow{2}{*}{ Aspek } & \multicolumn{1}{c|}{ Indikator } & \multicolumn{3}{c|}{ Skor Tiap Pertemuan } \\
\cline { 3 - 6 } & & P.1 & P. 2 & P.3 & P.4 \\
\hline $\begin{array}{l}\text { Langkah- } \\
\text { langkah } \\
\text { pembelajaran }\end{array}$ & $\begin{array}{l}\text { Keterlaksanaan kegiatan memahami masalah } \\
\text { kontekstual }\end{array}$ & 4 & 4 & 4 & 4 \\
\cline { 2 - 6 } & $\begin{array}{l}\text { Keterlaksanan kegiatan menjelaskan masalah } \\
\text { kontekstual }\end{array}$ & 4 & 4 & 4 & 4 \\
\cline { 2 - 6 } & $\begin{array}{l}\text { Keterlaksanaan kegiatan menyelesaikan } \\
\text { masalah kontekstual }\end{array}$ & 3 & 4 & 4 & 4 \\
\cline { 2 - 6 } & $\begin{array}{l}\text { Keterlaksanaan kegiatan membandingkan } \\
\text { atau mendiskusikan jawaban }\end{array}$ & 3 & 4 & 4 & 4 \\
\cline { 2 - 6 } & Keterlaksanaan kegiatan menyimpulkan & 3 & 4 & 4 & 4 \\
\hline \multirow{2}{*}{$\begin{array}{l}\text { Sistem sosial } \\
\text { pada } \\
\text { pelaksanaan } \\
\text { pembelajaran }\end{array}$} & Penciptaan suasana demokratis & 3 & 4 & 4 & 4 \\
\cline { 2 - 6 } & Siswa berkolaborasi dalam belajar & 3 & 4 & 4 & 4 \\
\cline { 2 - 6 } & Guru mengingatkan siswa untuk bekerjasama & 4 & 4 & 4 & 4 \\
\hline $\begin{array}{l}\text { Komunikasi transaksional antar siswa dan } \\
\text { antara siswa dengan guru }\end{array}$ & 3 & 3 & 3 & 4 \\
\hline prinsip reaksi & $\begin{array}{l}\text { Guru memberi kesempatan pada siswa } \\
\text { bertanya, mengungkapkan ide-ide secara } \\
\text { bebas dan terbuka }\end{array}$ & 4 & 4 & 4 & 4 \\
\hline
\end{tabular}




\begin{tabular}{|l|l|c|c|c|c|}
\hline & $\begin{array}{l}\text { Guru menyediakan dan mengelola sumber } \\
\text { belajar yang relevan }\end{array}$ & 4 & 4 & 4 & 4 \\
\cline { 2 - 5 } $\begin{array}{l}\text { Guru memberikan bantuan terbatas pada } \\
\text { siswa yang membutuhkan atau yang } \\
\text { mengalami kesulitan }\end{array}$ & 4 & 4 & 4 & 3 \\
\cline { 2 - 6 } $\begin{array}{l}\text { Guru menghargai pendapat siswa dan } \\
\text { mendorong siswa untuk berpikir kreatif }\end{array}$ & 4 & 4 & 4 & 4 \\
\cline { 2 - 5 } $\begin{array}{l}\text { Guru tidak cenderung memposisikan diri } \\
\text { sebagai sumber balajar tetapi memberi } \\
\text { kebebasan pada siswa mengemukakan } \\
\text { pendapat }\end{array}$ & 4 & 4 & 4 & 4 \\
\cline { 2 - 6 } & $\begin{array}{l}\text { Guru mengarahkan siswa untuk dapat } \\
\text { mengonstruksi pengetahuan }\end{array}$ & 3 & 3 & 3 & 3 \\
\hline Skor Total & $\mathbf{5 3}$ & $\mathbf{5 7}$ & $\mathbf{5 7}$ & $\mathbf{5 8}$ \\
\hline Rata-rata skor tiap pertemuan & $\mathbf{3 , 5 3}$ & $\mathbf{3 , 8}$ & $\mathbf{3 , 8}$ & $\mathbf{3 , 8 6}$ \\
\hline Rata-rata skor uji coba I & \multicolumn{3}{|c|}{ Terlaksana dengan baik } \\
\hline Kategori &
\end{tabular}

Berdasarkan Tabel 4., dapat dilihat bahwa rata-rata skor observasi keterlaksanaan pembelajaran dengan modul pembelajaran berbasis Realistic Mathematic Education (RME) yang dikembangkan berada pada kategori "Terlaksana dengan Baik" dengan skor 3,86. Skor sudah memenuhi kriteria keberhasilan kepraktisan modul pembelajaran dari segi keterlaksanaan pembelajaran

\section{Keefektifan}

Tingkat Ketuntasan Klasikal Tes Akhir Kemampuan Berpikir Kreatif Matematis Uji Coba II

Untuk melihat tingkat ketuntasan klasikal tes akhir kemampuan berpikir kreatif matematis uji coba II dapat dilihat pada Tabel 5.

Tabel 5.T ingkat Ketuntasan Klasikal Tes Akhir Kemampuan Berpikir Kreatif Matematis Uji Coba II

\begin{tabular}{|c|c|c|}
\hline \multirow{2}{*}{ Kategori } & \multicolumn{2}{|c|}{ Kemampuan Berpikir Kreatif Matematis } \\
\cline { 2 - 3 } & Jumlah Siswa & Persentase \\
\hline Tuntas & 25 & $96,16 \%$ \\
\hline Tidak Tuntas & 1 & $3,84 \%$ \\
\hline Jumlah & 26 & $100 \%$ \\
\hline
\end{tabular}

Berdasarkan Tabel 5. terlihat bahwa ketuntasan klasikal tes akhir kemampuan berpikir kreatif matematis siswa pada uji coba II adalah sebesar 96,16\%. Jadi, dapat disimpulkan bahwa pada uji coba II, penerapan modul pembelajaran berbasis Realistic Mathematic Education yang dikembangkan telah memenuhi kriteria pencapaian ketuntasan secara klasikal.

Observasi Aktivitas Siswa

Deskripsi rata-rata hasil observasi aktivitas siswa pada uji coba II dapat dilihat pada Tabel 6. 
Tabel 6. Deskripsi Rata-Rata Hasil Observasi Aktivitas Siswa Pada Uji Coba II

\begin{tabular}{|c|l|c|c|c|c|}
\hline \multirow{2}{*}{ No } & \multicolumn{1}{|c|}{ Pernyataan } & \multicolumn{3}{c|}{ Skor Per Pertemuan } \\
\cline { 3 - 6 } & & P.I & P.II & P.III & P.IV \\
\hline 1 & Memperhatikan penjelasan guru & 4 & 4 & 4 & 4 \\
\hline 2 & Memperhatikan penjelasan teman & 3 & 3 & 3 & 4 \\
\hline 3 & $\begin{array}{l}\text { Mmebaca sumber informasi tambahan dari } \\
\text { berbagai media }\end{array}$ & 4 & 4 & 4 & 4 \\
\hline 4 & $\begin{array}{l}\text { Membaca penjelasan yang ditampilkan di } \\
\text { modul pembelajaran }\end{array}$ & 4 & 4 & 4 & 4 \\
\hline 5 & $\begin{array}{l}\text { Memahami materi pada modul dan menjawab } \\
\text { pertanyaan yang diberikan }\end{array}$ & 3 & 3 & 3 & 4 \\
\hline 6 & Mencatat informasi penting dari modul & 3 & 4 & 4 & 3 \\
\hline 7 & $\begin{array}{l}\text { Menyelesaikan masalah-masalah yang ada pada } \\
\text { modul pembelajaran }\end{array}$ & 4 & 4 & 4 & 3 \\
\hline 8 & Merangkum penjelasan dari guru dan teman & 3 & 3 & 3 & 4 \\
\hline 9 & Berdiskusi/bertanya dengan teman & 3 & 3 & 4 & 4 \\
\hline 10 & Berdiskusi/bertanya dengan guru & 3 & 4 & 4 & 4 \\
\hline 11 & Mengganggu teman & 4 & 4 & 4 & 4 \\
\hline 12 & Keluar kelas sebelum waktunya & 4 & 4 & 4 & 4 \\
\hline Skor Total & 42 & 44 & 45 & 45 \\
\hline Rata-Rata Skor Tiap Pertemuan & 3,5 & 3,67 & 3,75 & 3,75 \\
\hline Rata-Rata Skor Uji Coba I & \multicolumn{3}{|c|}{3,69} & Aktif \\
\hline Kategori & \multicolumn{4}{|l}{} \\
\hline
\end{tabular}

Berdasarkan Tabel 6 diatas terlihat bahwa rata-rata skor observasi aktivitas siswa pada uji coba II selama pembelajaran dengan menggunakan modul pembelajaran yang dikembangkan berada pada kategori "aktif" dengan skor 3,69.

\section{Observasi Kemampuan Guru Mengelola Pembelajaran}

Deskripsi rata-rata hasil observasi kemampuan guru mengelola pembelajaran pada uji coba II dapat dilihat pada Tabel 7.

Tabel 7. Deskripsi Rata-Rata Hasil Observasi Kemampuan Guru Mengelola Pembelajaran Pada Uji Coba II

\begin{tabular}{|c|l|c|c|c|c|}
\hline \multirow{2}{*}{ No } & \multicolumn{1}{|c|}{ Pernyataan } & \multicolumn{4}{c|}{ Skor tiap Pertemuan } \\
\cline { 3 - 6 } & \multicolumn{1}{|c|}{ P.I } & P.II & P.III & P.IV \\
\hline 1 & Memberi motivasi untuk belajar kepada siswa & 4 & 4 & 4 & 4 \\
\hline 2 & Menyampaikan tujan pembelajaran & 4 & 4 & 4 & 4 \\
\hline 3 & Mengingat kembali materi prasyarat & 4 & 4 & 4 & 3 \\
\hline 4 & $\begin{array}{l}\text { Mengarahkan siswa untuk mengamati masalah yang } \\
\text { ditampilkan dalam modul pembelajaran }\end{array}$ & 4 & 4 & 4 & 4 \\
\hline 5 & $\begin{array}{l}\text { Memberikan pertanyaan-pertanyaan yang } \\
\text { menggiring siswa kepada suatu konsep }\end{array}$ & 3 & 3 & 3 & 4 \\
\hline 6 & $\begin{array}{l}\text { Menginstruksikan siswa untuk mencari informasi } \\
\text { atau memberikan informasi tambahan }\end{array}$ & 3 & 3 & 4 & 4 \\
\hline 7 & $\begin{array}{l}\text { Membimbing dan mengarahkan siswa untuk } \\
\text { berdiskusi }\end{array}$ & 3 & 4 & 4 & 4 \\
\hline 8 & $\begin{array}{l}\text { Mendorong siswa untuk berani menyampaikan } \\
\text { pendapatnya }\end{array}$ & 3 & 4 & 4 & 4 \\
\hline 9 & Menyimpulkan materi pelajaran & 4 & 4 & 4 & 4 \\
\hline
\end{tabular}


Pengembangan Modul Pembelajaran Berbasis Realistic Mathematic Education Untuk Meningkatkan Kemampuan Berpikir Kreatif Matematis Siswa Pada Materi Bangun Ruang Sisi Datar, Ade Siti Rahma, Edi Syahputra, Mulyono 991

\begin{tabular}{|c|l|c|c|c|c|}
\hline 10 & Menginformasikan materi pelajaran selanjutnya & 4 & 4 & 4 & 4 \\
\hline 11 & Ketepatan memulai pembelajaran & 4 & 4 & 4 & 4 \\
\hline 12 & Ketepatan pelaksanaan pembelajaran & 4 & 4 & 4 & 4 \\
\hline 13 & Ketepatan mengakhiri pembelajaran & 4 & 4 & 4 & 4 \\
\hline Skor Total & 48 & 50 & 51 & 51 \\
\hline Rata-Rata Skor Tiap Pertemuan & 3,69 & 3,84 & 3,92 & 3,92 \\
\hline Rata-Rata Skor Uji Coba I & \multicolumn{4}{|c|}{$\mathbf{3 , 8 6}$} \\
\hline Kategori & \multicolumn{4}{|c|}{} \\
\hline
\end{tabular}

Berdasarkan Tabel 7, terlihat bahwa rata-rata skor observasi kemampuan guru mengelola pembelajaran selama pembelajaran dengan menggunakan modul pembelajaran yang dikembangkan berada pada kategori 'Baik' dengan skor 3,81. Secara keseluruhan kesimpulan hasil uji coba I adalah sebagai berikut: 1) tingkat keterlaksanaan pembelajaran menggunakan modul pembelajaran yang di kembangkan berada pada kategori "Terlaksana dengan Baik"; 2) hasil tes akhir kemampuan berpikir kreatif matematis siswa menunjukkan bahwa pembelajaran dengan modul yang dikembangkan telah tuntas secara klasikal; 3) hasil observasi aktivitas siswa sudah memenuhi kriteria keaktifan yang ditetapkan; 4) nilai kemampuan guru mengelola pembelajaran tergolong baik. Dapat disimpulkan bahwa kriteria keefektifan terpenuhi.

\section{Deskripsi Peningkatan Kemampuan Berpikir Kreatif Siswa}

Peningkatan kemampuan spasial matematis siswa diperoleh dari data indeks gain ternormalisasi. Berdasarkan indeks gain ternormalisasi, diperoleh bahwa pada uji coba I terjadi peningkatan nilai sebesar 0,42 dengan kriteria sedang $(0,3<g \leq 0,7)$. Begitu juga pada uji coba II terjadi peningkatan nilai sebesar 0,44 dengan kriteria sedang $(0,3<g \leq 0,7)$. Peningkatan kemampuan berpikir kreatif matematis dapat dilihat pada Gambar 4.

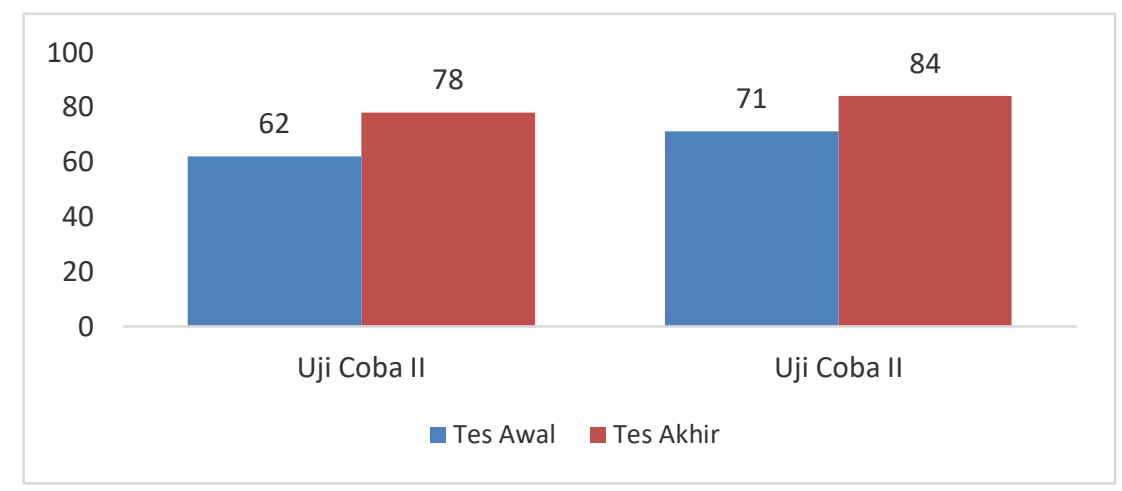

Gambar 4. Peningkatan Tes Akhir Kemampuan Berpikir Kreatif Matematis

\section{Diskusi}

\section{Pembahasan Hasil Validitas Modul Pembelajaran}

Berdasarkan hasil validasi modul pembelajaran berbasis Realistic Mathematic Education yang dikembangkan diperoleh bahwa modul pembelajaran ini valid atau memiliki derajat validitas yang baik. Selanjutnya, hasil validasi terhadap rencana pembelajaran (RPP), lembar aktivitas siswa (LAS), tes awal dan akhir kemampuan berpikir kreatif matematis juga valid. Hal ini berarti modul 
pembelajaran dan perangkatnya dapat memenuhi tuntutan kebutuhan pembelajaran untuk meningkatkan kemampuan berpikir kreatif matematis pada materi bangun ruang sisi datar.

\section{Pembahasan Hasil Kepraktisan Modul Pembelajaran}

Melalui lembar observasi keterlaksanaan pembelajaran dengan modul pembelajaran berbasis Realistic Mathematic Education yang dikembangkan yang diberikan kepada seorang observer di setiap pertemuan uji coba I dan II diperoleh hasil bahwa modul tersebut belum memenuhi kriteria kepraktisan pada uji coba I, yaitu dengan skor 2,7 pada pertemuan I, skor 2,8 pada pertemuan II, dan rata-rata 2,735 (kategori “Terlaksana dengan Kurang Baik"). Sedangkan pada uji coba II, diperoleh skor 3,53 pada pertemuan I, 3,8 pada pertemuan II, dan 3,8 pada pertemuan III. Rata-rata hasil observasi keterlaksanaan pembelajaran pada uji coba II adalah 3,71 dengan kategori "Terlaksana dengan Baik". Hasil ini sudah memenuhi kriteria keberhasilan kepraktisan. Sehingga, dapat disimpulkan bahwa modul pembelajaran berbasis Realistic Mathematic Education yang dikembangkan praktis.

Hal tersebut sejalan dengan Riyanto et al (Riyanto et al., 2017) dalam penelitian menyatakan "The validation and one-to-one result produced valid and practical mathematicl modeling problem in realistic mathematics education for learning mathematical modelling of material equations and system of linier equations of two variable”. Artinya proses validasi masing-masing modul pembelajaran menghasilkan model masalah matematika dalam RME yang valid dan praktis, khususnya pada materi SPLDV.

Selain itu juga sejalan dengan penelitian yang dilakukan oleh Chuseri (Chuseri et al., 2021) yaitu, berdasarkan aspek kevalidan dan kepraktisan modul memperoleh nilai > 2,5 maka modul memenuhi syarat kelayakan untuk sebuah modul. Media pembelajaran berupa modul matematika berbasis realistik ini dapat dimanfaatkan dalam proses pembelajaran matematika kelas V SD untuk melatih siswa lebih mandiri dalam belajar matematika. Selain itu juga dapat dimanfaatkan sebagai pegangan siswa dalam belajar secara individu atau mandiri.

\section{Pembahasan Hasil Keefektifan Modul Pembelajaran}

Ketuntasan klasikal tes akhir kemampuan berpikir kreatif matematis siswa pada uji coba I adalah sebesar 76,92\%. Jadi, dapat disimpulkan bahwa pada uji coba I, penerapan modul pembelajaran berbasis Realistic Mathematic Education yang dikembangkan belum memenuhi kriteria pencapaian ketuntasan secara klasikal ( $\geq 85 \%$ ). Namun, pada uji coba II, ketuntasan klasikal tes akhir kemampuan berpikir kreatif matematis siswa telah memenuhi kriteria yang ditentukan yaitu sebanyak 96,16\% siswa (25 orang) dinyatakan tuntas. Sehingga, dapat dikatakan bahwa modul pembelajaran berbasis Realistic Mathematic Education telah memenuhi kriteria keefektifan pada aspek ketuntasan klasikal. Hal tersebut sejalan dengan pendapat Maulidya, Surya dan Syahputra (Maulidya et al., 2017) pada penelitiannya yaitu "we can conclude that a teaching material that has developed through RME has been effective to use". Mereka menyatakan bahwa modul pembelajaran yang dikembangkan 
melalui RME bisa efektif untuk digunakan. Kedua penelitian ini menunjukkan bahwa pengembangan modul dengan RME dapat memperoleh modul yang valid dan efektif untuk digunakan.

\section{Peningkatan Kemampuan Berpikir Kreatif Matematis Siswa}

Berdasarkan hasil analisis tes kemampuan berpikir kreatif matematis siswa pada uji coba I dan uji coba II menunjukkan bahwa terdapat peningkatan kemampuan berpikir kreatif matematis siswa. Peningkatan ini terlihat dari rata-rata hasil tes kemampuan berpikir kreatif yang diperoleh siswa. Berdasarkan indeks gain ternormalisasi, diperoleh bahwa pada uji coba I terjadi peningkatan nilai sebesar 0,42 dengan kriteria sedang $(0,3<g \leq 0,7)$ dan pada uji coba II terjadi peningkatan nilai sebesar 0,44 dengan kriteria sedang $(0,3<g \leq 0,7)$. Selain itu hasil uji paired sample $t$ test juga menunjukkan hal yang sama, dimana nilai sig. untuk uji coba I dan uji coba II masing-masing sebesar 0,000 dan lebih kecil dari $0,05(0,000<0,05)$. Sehingga dapat disimpulkan bahwa terjadi peningkatan yang signifikan pada kemampuan berpikir kreatif matematis siswa. Sehingga dapat disimpulkan bahwa modul pembelajaran berbasis Realistic Mathematic Education yang dikembangkan ini dapat meningkatkan kemampuan berpikir kreatif matematis siswa.

Hal tersebut sejalan dengan penelitian Zakaria (Zakaria, 2017) yang menyimpulkan "Use of Realistic Mathematics Education Approach can enhanced mathematic achievement of students". Hal ini bermakna bahwa menggunakan RME dapat meningkatkan prestasi matematika siswa. Dari hasil penelitian sebelumnya ini terlihat RME memiliki keunggulan dalam hal meningkatkan kemampuan matematik seperti kemampuan penalaran, spasial pemahaman konsep dan dalam penelitian ini yang akan ditingkatkan adalah berpikir kreatif matemaatis.

Hasil tersebut juga sejalan dengan penelitian istikomah (Istikomah et al., 2020) yang menyimpulkan bahwa e-modul berbasis realistik dapat meningkatkan kemampuan berpikir kreatif siswa, karena e-modul mudah dipahami oleh siswa dengan menggunakan basis realistik.

\section{KESIMPULAN}

1. Validasi modul pembelajaran berbasis Realistic Mathematic Education yang dikembangkan berada pada kategori 'Valid' ditinjau dari analisis hasil validitas modul pembelajaran oleh validator dengan nilai rata-rata total sebesar 3,78.

2. Modul pembelajaran berbasis Realistic Mathematic Education yang dikembangkan memenuhi kriteria keberhasilan kepraktisan modul pembelajaran ditinjau dari hasil observasi keterlaksanaan pembelajaran. Skor yang diperoleh pada uji coba II skor observasi keterlaksanaan pembelajaran adalah 3,71 dengan kategori "Terlaksana dengan Baik".

3. Modul pembelajaran yang dikembangkan telah memenuhi kriteria keefektifan yang ditetapkan. Pada uji coba II ketuntasan klasikal kemampuan berpikir kreatif matematis siswa sebesar 96,16\% (25 siswa). Rata-rata skor observasi aktivitas siswa adalah 3,64 (kategori aktif) pada uji coba II. Rata-rata skor observasi kemampuan guru mengelola pembelajaran adalah 3,81 (kategori baik) pada uji coba II. 
4. Berdasarkan indeks gain ternormalisasi, diperoleh bahwa pada uji coba I terjadi peningkatan nilai sebesar 0,42 dengan kriteria sedang $(0,3<g \leq 0,7)$ dan pada uji coba II terjadi peningkatan nilai sebesar 0,44 dengan kriteria sedang $(0,3<g \leq 0,7)$. Sehingga dapat disimpulkan bahwa modul pembelajaran berbasis Realistic Mathematic Education yang dikembangkan ini dapat meningkatkan kemampuan berpikir kreatif matematis siswa.

\section{UCAPAN TERIMA KASIH}

Terima kasih saya ucapkan kepada dosen pembimbing Bapak Bapak Prof. Dr. Edi Syahputra, M.Pd. dan Dr. Mulyono, M.Si. Terima kasih juga saya ucapkan untuk semua pihak yang membantu dalam menyelesaikan penelitian ini.

\section{REFERENSI}

Ataji, H. M. K., \& Sujarwanta, A. (2020). Analisis Pentingnya Pengembangan Modul Berbasis Video Assistant Menggunakan Link Qr Code Tentegrasi Alquran Dan Hadis Materi Sma Sistem Reproduksi Manusia. Biolova, 1(1), 48-55.

Chisara, C., Hakim, D. L., \& Kartika, H. (2018). Implementasi Pendekatan Realistic Mathematics Education (RME) DAlam Pembelajaran Matematika. Prosiding Seminar Nasional Matematika Dan Pendidikan Matematika (Sesiomadika) 2018, 65-72. http://journal.unsika.ac.id/index.php/sesiomadika

Chotimah. (2015). Upaya Meningkatkan Kemampuan Komunikasi Matematik Siswa SMP Di Kota Bandung Dengan Pendekatan Realistic Mathematics Education Pada Siswa SMP Di Kota Bandung. Jurnal Ilmiah STKIP Siliwangi Bandung, 9(1), 26-32.

Chuseri, A., Anjarini, T., \& Purwoko, R. Y. (2021). Pengembangan Modul Matematika Berbasis Realistik Terintegrasi Higher Order Thinking Skills (HOTS) Pada Materi Bangun Ruang. Alifmatika: Jurnal Pendidikan Dan Pembelajaran Matematika, 3(1), 18-31. https://doi.org/10.35316/alifmatika.2021.v3i1.18-31\%0D

Hamdani. (2011). Strategi Belajar Mengajar. Pustaka Setia.

Hendriana, H., Rohaeti, E. E., \& Sumarmo, U. (2017). Hard Skills dan Soft Skills Matematik Siswa. Refika Aditama.

Istikomah, Purwoko, R. Y., \& Nugraheni, P. (2020). Pengembangan E-Modul Matematika Berbasis Realisik Untuk Meningkatkan Kemampuan Berpikir Kreatif Siswa. MAJU, 7(2), 63-71.

Lasmiyati, \& Idris, H. (2014). Pengembangan Modul Pembelajaran untuk Meningkatkan Pemahaman Konsep dan Minat SMP. PYTHAGORAS: Jurnal Pendidikan Matematika, 9(2), 161-174.

Maulidya, Surya, \& Syahputra. (2017). The Development Of Mathematic Teaching Material Through Realistic Mathematics Education To Increase Mathematical Problem Solving Of Junior High School Students. IJARIIE, 3(2).

Mayasari, Ranapuri, Nursafitri, Handayani, \& Hidayat. (2018). Analisis Kemampuan Berpikir Kreatif 
Pengembangan Modul Pembelajaran Berbasis Realistic Mathematic Education Untuk Meningkatkan Kemampuan

Berpikir Kreatif Matematis Siswa Pada Materi Bangun Ruang Sisi Datar, Ade Siti Rahma, Edi Syahputra, Mulyono 995

Matematis Siswa Kelas Viii Smp Pada Sistem Persamaan Linear Dua Variabel (SPLDV). Jurnal Pendidikan Tambusai., 2(6), 1762-1771.

Moma, L. (2016). Pengembangan Instrumen Kemampuan Berpikir Kreatif Matematis untuk Siswa SMP. Delta-Pi: Jurnal Matematika Dan Pendidikan Matematika, 4(1), 27-41. http://ejournal.unkhair.ac.id/index.php/del tapi/article/view/142

Noviarni. (2014). Perencanaan Pemebelajaran Matematika dan Aplikasinya Menuju Guru Matematika yang Kreatif dan Inovatif (B. Media (ed.)).

Putra, H. D., Akhdiyat, A. M., Setiany, E. P., \& Andiarani, M. (2018). Kemampuan Berpikir Kreatif Matematik Siswa SMP di Cimahi. 98, 47-53.

Putri, Hasratuddin, \& Syahputra. (2019). Development of Learning Devices Based on Realistic Mathematics Education to Improve Students' Spatial Ability and Motivation. International Electronic Journal of Mathematics Education, 14(2).

Riyanto, Zulkardi, Putri, \& Darmawijoya. (2017). Mathematical modeling in realistic mathematics education. Journal of Physics Conference Series. doi: 10.1088/1742-6596/943/1/012049

Surya, E., \& Syahputra, E. (2017). Improving High-Level Thinking Skills by Development of Learning PBL Approach on the Learning Mathematics for Senior High School Students. International Education Studies. International Education Studies, 10(8).

Thiagarajan, Semmel, M. (1974). Instructional Development for Training Teachers of Exceptional Children. Central for Innovation on Teaching The Handicapped.

Zakaria. (2017). The Effect of Realistic Mathematics Education Approach on Students' Achievement and Attitudes Towards Mathmatics. Mathematics Education Trends and Research, 1, 32-40.

Zaqiyah, K., Lutfitah, \& Sulisawati, N. D. (2020). Pengembangan Modul Berbasis Realistic Mathematics Education untuk Pembelajaran Bangun Ruang Sisi Lengkung. LAPLACE : Jurnal Pendidikan Matematika, 3(2), 151-162. 